\title{
FROM CONTROVERSY TO TOLERANCE Dynamics of the Development of Istiqomah Mosque in Front of a Church in Ungaran Central Java Indonesia
}

\author{
Muh. Saerozi \\ IAIN Salatiga - Indonesia| saerozi2010@yahoo.com
}

\begin{abstract}
This study aims to reveal the dynamic of the development of a mosque in front of a church: the case study of Istiqomah Mosque of Ungaran. The dynamics of the development is seen from some factors that encouraged the establishment of the mosque, the phenomenon of controversy, the problem solution, and the development of tolerance model. The study uses a historical-qualitative approach. The primary data are gathered from interviews, documentation, and observation. The purposes of building the mosque were to balance the national development, to prevent the influence of the Partai Komunis Indonesia (PKI, Indonesian Communist Party), and to create a symbol of tolerance. Controversy occurred in the process of construction because some political and religious elites considered the mosque as political Islam. The controversy waned after the New Order's elites supported the construction of the mosque. The implementation of a moderate Islamic principles influenced the mosque in building tolerance to the Kristus Raja church in front of it.
\end{abstract}

Keywords: Istiqomah Mosque, Kristus Raja Church, tolerance, Moderate Islam, the New Order regime.

\section{Introduction}

One of the characteristics of plurality in Indonesia is the existence of a mosque in front of a church. The phenomenon is not only in the predominantly Muslim areas, such as in Jakarta and Central Java ${ }^{1}$, but

1 Istiqlal Mosque and Katedral Church in Jakarta. http://www.tribunnews.com/travel/2015/09/14/masjid-istiqlal-dan-gereja-katedral-sengaja-dirancang-berdampingan 
also in the predominantly Catholic areas, such as in East Nusa Tenggara. ${ }^{2}$ Another characteristic of plurality is the existence of a mosque adjacent to a church. This phenomenon is not only happening in Java, such as Banten, Central Java, and East Java provinces ${ }^{3}$, but also outside of Java, such as in Southeast Sulawesi and West Kalimantan. ${ }^{4}$

During an interfaith disharmony takes place in Indonesia, a mosque adjacent to a church is often bloated up as a symbol of tolerance. ${ }^{5}$ The purpose of reporting it is to strengthen the interfaith tolerance. However, some publics are very critical to the phenomenon. They asked about the real tolerance between the mosque and the church. The question is quite rational, because in certain regions, some mosques are built after the churches. Some of the previous studies have not been able to answer the questions comprehensively about mosques adjacent to churches. The recent researches on the theme

simbol toleransi- ide-bung-karno. accessed on January 28, 2017. Istiqlal Mosque dan Kristus Raja Church in Central Java. http://okberita.com/merajut-jembatanpersaudaraan-sejati/, accessed on January 18, 2017.

2 The Great Mosque of Al-Ghuraba Baiturrabman and Masebi Injili Church in Timor (GMIT) Ebenhaezer. https://rangkaijejak.wordpress.com/ 2014/09/26/ kota-dinginbajawa/., accessed on January 26, 2017.

3 Yesus Kristus Church and Awwabin Mosque in Sepatan, Tangerang. http://www.hipwee.com/feature/masih-ribut-ribut-soal-tolikara-masjid-dan-gereja-

ini-bertahun-tahun-hidup-berdampingan-dengan-damai/ accessed on January 26, 2017; Kristen Jawa Church (GKJ) Joyodiningratan and Al-Hikmah Mosque in Solo. http://jogja.tribunnews.com/2015/07/21/wow-masjid-dan-gereja-di-solo-ini-saling-

berdampingan. accessed on January 28, 2017. National Mosque of Al-Akbar of Surabaya and Sakramen Maha Kudus Catholic Church of Pagesangan. http://www.antarajatim.com/lihat/ berita/126757/dubes-as-apresiasi-masjid-al-akbargereja-berdekatan. Assecced on January 26, 2017.

4 Bukit Zaitun Church and Da'wah Wanita Kendari Mosque http://www.kompasiana.com/mahajinoesa/sejuknya-mesjid-dan-gereja-berhimpit-di-kota-kendari55ace4ffb27a616c080d4b58, assecced on January 26, 2017.; Nurbaitillab Mosque and Huria Kristen Batak Protestan Church in Jeruju, Pontianak http://www.matakalbar.com/ baca/653/ 2014-10-02/ masjid.dan.gereja. berdiri. berdampingan.sebagai. simbol.toleransi, assecced on January 27, 2017.

5 See in; http://www.hipwee.com/feature/masih-ribut-ribut-soal-tolikara-masjid-dangereja-ini-bertahun-tahun-hidup-berdampingan-dengan-damai/. Accessed on January 26, 2017. http://wongcrewchild.blogspot.co.id/2014/12/simbol-toleransi-di-alunalun-kota.html. accessed on January 26, 2017. 
mostly use a qualitative approach to a case study ${ }^{6}$ or historical approach with a different context. ${ }^{7}$ Therefore, a new research on the object of different mosque and church is needed.

This research is conducted in order to find new answers about the phenomenon of mosques and churches adjacent to one another in one location. The research focuses on the Istiqomah Jami Mosque of Ungaran Central Java. The reasons of why the mosque is to be the object of the research are: the first, the position of the mosque is in front of the church. Between the mosque and the church is only separated by a highway. The second, the church was built earlier than the mosque. ${ }^{8}$ The third, the Istiqomah Mosque is categorized as a Jami Mosque. ${ }^{9}$ The Kristus Raja Church is categorized as a Parokhi. ${ }^{10}$ The Fourth, the physical buildings of the mosque and the church are quite large. The fifth, both of the church and mosque have a school inside.

${ }^{6}$ For example, Sidqon Maesur, "Kafakuman Masjid Walisongo Lempuyangan yang Berdampingan dengan Gereja Kristen Jawa (GKJ) di Dusun Lempuyangan, Desa Timpik, Kecamatan Susukan, Kabupaten Semarang Jawa Tengah," Research Report (Salatiga: Pusat Penelitian dan Pengabdian Masyarakat (P3M) Sekolah Tinggi Agama Islam Negeri (STAIN) Salatiga, 2014); Nira Nurazizah wrote about the Christian's and Moslem's attitudes toward the existence of the mosques and churches nearby in Sarijadi Bandung (http://pa.uinsgd.ac.id/sikap-umat-beragama-kristen-dan-islamterhadap-keberadaan-masjid-dan-gereja-yang-berdekatan-lokasinya-di-sarijadi-

bandung/ accessed on January 26, 2017); Seán McLoughlin, "The Mosque-Centre, Community-Mosque: Multi-Functions, Funding and the Reconstruction of Islam in Bradford," Scottish Journal of Religious Studies, 19, 1998, 211-228.

7 Sidney H. Griffith, "the Church in the Shadow of the Mosque: Christians and Muslims in the World of Islam," Religious Studies Review, Vol. 35 Number 2 (June 2009): pp. 134-135; Nuha n.n. Khoury, "The meaning of the Great Mosque of Cordoba in the Tenth Century," Muqarnas, Vol. 13 (1996): pp. 80-98; Jonathan M. Bloom and T. W. Gaehtgens, "Mosque Towers and Church Towers in Early Medieval Spain," 1993 (http://www.openbibart.fr/item/display/10068/1077878. accessed on June 7, 2017). Julie A. Harris, "Mosque to Church Conversions in the Spanish Reconquest," Medieval Encounters Vol. 3 (1997): pp. 158-172.

8 The cornerstone-laying of the church's construction wan on January 22, 1933. Rm. Al. Budyapranata, Buku Kenangan Peringatan 64 Tabun Gereja Kristus Raja Ungaran (Ungaran: Panitia HUT Paroki, 1997), p. 9. The cornerstone-laying of the mosque construction was on February 9, 1979. (taken from the document of the process of mosque construction)

9 Notarial Deed of the establishment of the Istiqomah foundation, Notary H. Pandji Surya SH., Notary in Semarang Jl. Let. Jend. M.T. Haryono No. 515, Copy, September 28, 1978, Number 6.

${ }^{10}$ Budyapranata, Buku Kenangan, pp. 8-9. 
And the sixth, the history of the church has been published, while the history of the mosque has not been written by anyone.

To answer these questions, the author uses a historical approach. The event, which investigated, is from the mosque's planning from 1978 up to the recent development in 2016. The period of the research will be divided into several chapters according to the characteristics of the event. ${ }^{11}$ The sources of the data are: First, archive of meeting, photos of activities, notarial deed of the foundation, and some other important documents relating to the mosque. Second, the inscription contained in the mosque environment. Third, literature and news about Istiqomah Mosque. Fourth, explanations from the perpetrators of the history of the mosque construction.

To find the data, the author tries to: first, dismantle the archive documents of the office of Istiqomah foundation. In addition, the author also traces the documents that are still stored by the exfoundation board. Second, the author tries to learn and understand the inscription of the mosque. Third, conducting an interview to some perpetrators of the history, family, or close friends. ${ }^{12}$ Fourth, browsing the news about Istiqomah Mosque. Fifth, doing observation on activities in the mosque. The author then does data selection, classification, and arrangement in accordance with the characteristic of events and stages of the time from 1978 to 2016. Interpretation of the data is done carefully based on the information contained in Islamic literatures and politics in Indonesia.

\section{Driving Factors of the Mosque Construction}

Ungaran is a part of Semarang Regency of Central Java Province. ${ }^{13}$ The city becomes a capital of Semarang Regency since $1971 .{ }^{14}$ Ungaran

\footnotetext{
${ }^{11}$ Kuntowijoyo, Penjelasan Sejarah (Yogyakarta: Tiara Wacana, 2008), pp. 5-6, pp. 19-34.

12 Some of the founders and administrators of the foundation are elderly, and the other have died. Their residents have also been scattered in Jakarta, Salatiga, Ungaran, Yogyakarta, and Semarang.

${ }^{13}$ This area lies at position This area lies at position $110^{0} 14^{1} 54^{11}$ to $110^{0} 39^{1} 3^{11}$ East Longitude and $7^{0} 3^{1} 57^{11}$ to $7^{0} 30^{1} 54^{11}$ South Latitude. The total area of Semarang regency is $95,020,674 \mathrm{Ha}$ or about $2.92 \%$ of the total area of Central Java Province. The width of Semarang regency extends from Demak regency in the north - Grobogan regency in the west - and Boyolali, Temanggung, and Magelang regencies in the east. (https://id.wikipedia.org/wiki/Kabupaten_Semarang. accessed on April 20, 2017).

14 The capital of Semarang regency was originally in the area Kanjengan (Pasar Johar) Semarang. Nurudin Zanki, "Perpindahan Ibukota Pemerintahan Kabupaten Semarang
} 
is a very strategic and sensitive area of the various aspects because it becomes a land transportation crossing from Semarang to Solo and Yogyakarta. The Ungaran's highway is also crossing from Semarang to Cilacap and Purwokerto. The majority of the population of Ungaran is Muslim, so it has many mosques. Of the many mosques, only some are on the side of the highway. ${ }^{15}$ On the other hand, Unggaran has also many churches. Of the churches, only few are on the side of the highway. In addition to a number of mosques and churches, Ungaran also has Vihara. ${ }^{16}$

The mosques in Ungaran, borrowing Hasan Asari's opinion, can be categorized into two, namely "jami mosque" and "mosque". The mosque is only used for the daily five prayers, while the jami' mosque serves for Friday prayers and governmental interests. ${ }^{17}$ The mosque that is categorized as jami' in Ungaran is Raudat al-Muttaqin Kauman Mosque. It is located behind the Kawedanan government office of Ungaran. ${ }^{18}$ The adjacency of Kauman Raudat al-Muttaqin Mosque to the center of the government is a specific character that differs from the other mosques.

The scarcity phenomenon of jami' mosque on the roadside happens in some areas, namely Ungaran, Solo and Magelang. ${ }^{19}$ From Ungaran to Solo, the only jami mosque found is jami' mosque in Kauman Salatiga. From Ungaran to Magelang only found jami' mosque

dari Kota Semarang Ke Kota Ungaran Tahun 1971-1983," Journal of Indonesian History, Vol. 3 No. 1 (2014), p. 47.

15 Al-Mustaqim mosque is in Gowongan, Mujabidin mosque is Mijen, and Wabyu mosque is in Langensari. Those mosques are only small. Other mosques are some distance from the highway, such as Raudat al-Muttaqin mosque in Kauman, Syeikh Abdul Al-Rabman mosque in Jambon, Al-Miftah mosque in Kuncen, and Bait al-Syukur mosque in Genuk Krajan.

16 https://www.tripadvisor.co.id/ShowUserReviews-g3207850-d8326958-r280793216Avalokitesvara_Sri_Kukusrejo_Temple-Ungaran_Central_Java_Java.html. Accessed on April 18, 2017.

${ }^{17}$ Hasan Asari, Zaman Keemasan Islam: Kajian atas Lembaga-lembaga Pendidikan (Bandung: Mizan, 1995), pp. 29-41.

18 Ungaran before September 1983 was Kawedanan. The capital of Semarang was in Kanjengan, Semarang. http://www.suaramerdeka.com/harian/0612/20/kot31.htm, accessed on February 5, 2017. Since 1971, the Kawedanan office is used as the regent of Semarang's office and official residence. See Zanki, "Perpindahan Ibukota Pemerintahan Kabupaten Semarang, p. 47.

${ }^{19}$ Interview with Soesmono Martosiswojo, the former Regent of Semarang as an exofficio of the chairman of the Istiqomah foundation in 1979-1985, May 3, 2015. 
in Payaman, Magelang. In addition to the two jami' mosques, there are only small mosques or langgar.

The condition of Unggaran without a strategic jami' mosque, Iswarto as a Regent (Bupati) of Semarang (1969-1979) was motivated to fill the void. There were two purposes behind the local leader's motivation: first, to make a jami' mosque as a symbol of balance of the development in Semarang. It means that the development is not merely focused on physical infrastructures, but also on spiritual aspects of life. Second, creating a symbol of functional harmony between religious believers for the community. ${ }^{20}$

The purpose of the Regent to build a mosque was relevant to the national development objectives at that time. The national development aimed to create a "just and prosperous society as well as equal material and spiritual development based on Pancasila (the five principles) within the independent and sovereign of the Republic of Indonesia ...". ${ }^{21}$ The motivation was also relevant to the government program of religious field. One of the government's programs was to build places of worship, especially in the centralized areas of industry and the base area of $\mathrm{G} 30 \mathrm{~S} / \mathrm{PKI} .^{22}$

The idea of the Regent of Semarang to build a jami' mosque was not only relevant to the national development plan, but also to the condition of Semarang Regency. First, industrialization began to appear in Ungaran. The factories stood and produced gradually. ${ }^{23}$

${ }^{20}$ Interview with Mohammad Ridwan, one of the Istiqomah foundation founders. June 13, 2015. He is now the imam of Istiqomah mosque.

21 Departemen Penerangan RI, Lampiran Keputusan Presiden RI Nomor 11 tabun 1974 tentang Rencana Pembangunan Lima Tabun Kedua (1974/75-1978/79), Vol. I (Jakarta: Departemen Penerangan RI, 1974), p. 17.

22 Departemen Penerangan RI, Lampiran Keputusan Presiden RI Nomor 11 tabun 1974 tentang Rencana Pembangunan Lima Tabun Kedua (1974/75-1978/79), Vol. III (Jakarta: Departemen Penerangan RI,1974), pp. 124-125.

23 For example, PT Batam Textile was built in 1971 (http://batamtex.com/nw/ index.php? option $=$ com_content\&task $=$ view\&id $=6 \&$ Itemid $=29$, Accessed on February 4, 2017; PT Ungaran Sari Garment has operated since 1975. (http://swa.co.id/swa/trends/management/ungaran-sari-garment-kuasai-amerika, accessed on February 3, 2017); PT Nissin Biscuit Indonesia was operated in 1977. (https://www.translate.com/english/pt-nissin-biscuit-indonesia-didirikan-padaungaran-jawa-tengah-indonesia-pada-8-hektar-ini-mulai/25516800, Accessed on January 3, 2017).; PT Poliplas Indah Sejahtera was operated in 1982 (http:// www. lokerindonesia.com/ teknik/lowongan-supervisor- produksi-pt-poliplas-makmursantosa.html. accessed on February 3, 2017); PT. Pan Java Bottling Company (PT. 
Ungaran began to be the migrational destination of the surrounding sub-districts and districts. Some women who initially participated in farming began to enter industrial sectors. Industrialization in any parts of the world, according to Koento Wibisono, is susceptible to the current of positivism and all of its effects. ${ }^{24}$ The effects here mean the ethical, economic, demographic, political, cultural, sociological, and even ideological effects.

On the other hand, the New Order government has chosen the national development prioritized in the field of industrial sector as well as economy. ${ }^{25}$ From here it began to emerge dilemmatic problems between the current of industrialization and the mission of religiosity. The local government anticipated the effects of industrialization by creating a functional symbol of religiosity for society. The symbol of religiosity chosen in Ungaran was the jami' mosque. The presence of jami' mosque theoretically represents religious as well as political power. The local government uses the mosque for their political interests and as their responsibility for their institutional development. ${ }^{26}$

Secondly, the Indonesian Communist Party (PKI) was not only found in Semarang Regency, but it had ever won in the 1955 general election. PKI received 143,738 votes against the other major parties, such as Indonesian National Party (PNI), Nahdlatul Ulama (NU) Party and Indonesian Muslim Syura Assembly (Masyumi) Party. ${ }^{27}$ PKI in a political perspective of the New Order government was not only forbidden, but it was also cleansed to its ideological roots. The government apparatus were assigned to increase public awareness to

Coca-Cola Amatil Indonesia) was operated in Desember 5, 1976 (http:// ejournal.uajy.ac.id/3925/3/2KOM03842. pdf. Accessed on February 3, 2017).

24 Koento Wibisono, Arti Perkembangan Menurut Filsafat Positivisme Anguste Comte (Yogyakarta: Gadjah Mada University Press, 1983), 106.

${ }^{25}$ Departemen Penerangan RI, Lampiran Keputusan Presiden RI No. 4 Tabun 1974, Vol I, p. 23; Departemen Penerangan RI, Lampiran Keputusan Presiden RI Nomor 11 tahun 1974 tentang Rencana Pembangunan Lima Tabun Kedua (1974/75-1978/79), vol. II, (Jakarta: Departemen Penerangan RI,1974), p. 205.

${ }^{26}$ Hasan Asari, Zaman Keemasan Islam, p. 31.

27 Santoso Minarno, "Strategi PNI dalam memenangkan pemilihan umum 1955 di Jawa Tengah," Unpublished bachelor thesis (Semarang: Program Studi Ilmu Sejarah Jurusan Sejarah Fakultas Ilmu Sosial Universitas Negeri Semarang, 2011), p. 107. 
PKI. ${ }^{28}$ To carry out the task, the Regent intended to build a mosque as a symbol of resistance to PKI. ${ }^{29}$

Third, the population of Semarang has diverse religions, ${ }^{30}$ The beliefs in the One Almighty God. ${ }^{31}$ On the other hand, the communities were to live in harmony so that the national stability was maintained and the socio-economic life could increase. ${ }^{32}$ To enhance such harmony, the Regent would imitate the central government in creating a symbol of harmony. The central government at that time was supporting the settlement of the Istiqlal Mosque located in front of the Church. ${ }^{33}$ Opportunity to imitate the central government was widely opened in Ungaran, because this city had similarities to Jakarta in the diverse beliefs and religions for the people. ${ }^{34}$

To realize the jami' mosque, the Regent worked with some Muslim scholars and politicians. The scholars were mostly from the Islamic organization of Nahdlatul Ulama (NU) and Muhammadiyah, ${ }^{35}$ the

${ }_{28}$ Departemen Penerangan RI, Lampiran Keputusan Presiden RI Nomor 11 tabun 1974, Vol. I, p. 34.

29 The regent of Semarang (Iswarto) was a Muslim who had a PNI political background. Interview with Sarjono, March 26, 2017. Sarjono admitted that at that time he had become a teacher in a Junior High School in Ungaran, thus he could understand the political affiliation of the officials.

30 The religions which were commonly called at that time were Islam, Protestant, Catholic, Hindu, and Buddhist. See Departemen Penerangan RI, Lampiran Keputusan Presiden RI Nomor 11 tabun 1974, Vol. III, p. 118, and p. 125.

${ }^{31}$ Interview with Tatik Koesnadi on June 19, 2016. She became a teacher and Principal of Junior High School of the '70s in Ungaran, thus she understood her friends who followed the faith.

32 Departemen Penerangan RI, Lampiran Keputusan Presiden RI Nomor 11 tabun 1974, Vol. III, pp. 123-126.

33 Ibid., p. 125

${ }^{34}$ Location: village map Blat 3 F6 Jl. Diponegoro. Total land area 3,563 M2. (Archive of Istiqomah Foundation, a copy of Land Book from the Sub-Directorate of Agrarian Office of Semarang Regency, number 1203989). At this location there are Schools and Fields. The local people recognize this location as the "sacred field". Interview with Yasin Anwar on June 7, 2016. He is a leading figure and lives in Genuk Barat Ungaran. Yasin Anwar, during childhood, attended the Elementary School located next to the field.

35 The NU scholars, such as Kyai Zubair, Kyai Dimyati, Kyai Ghufron, Kyai Dja'farin Achmad, and Mochammad Fathony. The Muhammadiyah scholars, such as $\mathrm{H}$. Mohammad Masyhadi Abdul Majid, K.H. Mansyur, Azin Baidlowi, and some other administrators, such as Mrs Mashadi, Raden Soejitno Notohardjono, and Soepeno Hadi. (Notarial Deed of the establishment of Istiqomah foundation, Notary H. Pandji 
politicians of Golkar and the United Development Party's (PPP). ${ }^{36}$ They agreed to form a foundation and become its main caretaker. The foundation's name was "Istiqomah Jami' Mosque Foundation". ${ }^{37}$ The chairperson of the foundation was held ex-officio by the Regent of Semarang. ${ }^{38}$ All of the mosque constructional activities were under the responsibility of this foundation.

In theological and ideological sense, the foundation was moderate. This characters appeared in the foundation's principles that unite Islam as the religion and Pancasila as the basis of the state. The moderate character of the mosque also appeared on the foundation's aim to assist the government in realizing the appreciation and practice of the Pancasila. ${ }^{39}$ Istiqomah foundation also became a forum of the Muslim scholars of Nahdhatul Ulama and Muhammadiyah that they were representatives of Muslims in Semarang Regency. Differences in the point of view between Nahdhatul Ulama and Muhammadiyah gained a natural middle ground in the foundation.

The moderate character of the foundation was a mutualistic symbiotic product among the interest of the rulers, politicians, and ulama (Muslim scholars). This symbiosis pattern often occured in history, though the results varied. For example, the symbiosis between the Mu'tazilah's and al-Makmun's scholars (813-833 H) in Baghdad resulted in the Bayt al-Hikmah institution. ${ }^{40}$ The symbiosis of Shi'ah and al-Hakim's scholars $(1005 \mathrm{H})$ in Egypt resulted in the Dar al-Hikmah

Surya SH, Notary in Semarang Jalan Lt. Jend No. M.T. Haryono No. 515, Copy, September 28, 1978, Number 6).

36 The Golkar's politicians, such as Sipar Hardjosoemarto as DPRD's Chairman and Golkar DPD's Chairman, Mrs Masdiro as DPRD's member from Golkar. And the PPP's politician namely Mohammad Dja'farin Achmad (Notarial Deed of the establishment of Istiqomah foundation, Notary H. Pandji Surya SH., Notary in Semarang Jalan Let. Jend. M.T. Haryono No. 515, Copy, September 28, 1978, Number 6).

${ }^{37}$ Hans Wehr, A Dictionary of Modern Writen Arabic, J. Milton Cowan (ed.) (London: Macdonald \& Evans Ltd., 1974), p. 801.

${ }^{38}$ Notarial Deed of the Establishment of Istiqomah Foundation, Notary H. Pandji Surya SH, Notary in Semarang Jalan Lt. Jend No. M.T. Haryono No. 515, Copy, September 28, 1978, Number 6)

${ }^{39}$ Ibid.

${ }^{40}$ Charles Michael Stanton, Pendidikan Tinggi dalam Islam, trans. H. Afandi and Hasan Asari (Jakarta: Logos, 1994), p. 95. 
institution of Shi'ah. ${ }^{41}$ The symbiosis of Sunni-Ash'ari scholars and the Prime Minister of Nidzam al-Mulk in Baghdad produced Madrasab Nidzamiyah $(1064 \mathrm{H}) .^{42}$

\section{Controversy of the Mosque Construction: Causes and Impacts}

The document shows that the foundation's boards held the first cornerstone-laying event on February 9, 1979. Officials, figures, students, and scout members witnessed the ceremonial event. ${ }^{43}$ The first cornerstone-laying event impressed the board's cohesiveness. They were optimistic that the process of construction would smoothly be in completion. However, the reality was just the opposite. The process of building the mosque stopped completely after the cornerstone-laying event. At the construction site, only visible old school that still survived and huge holes excavations. The committee did not work on the construction site. They asked each other and waited for the instructions from the chairperson. ${ }^{44}$

The process of the construction ceased not because of funding factors, but it was caused by the initial funding to begin the construction has been readily available. The committee was also able to mobilize funds from the community, as often happened in the construction of the other mosques. Another proof that the process of the construction ceased not because of the funds was explained by Mohammad Ridwan as a treasurer. At that time, he came alone to the Regent's office and suggested that the construction process was to be continued. After hearing the explanation of Mohammad Ridwan, the Regent then replied briefly "You are a little boy do not know politics". ${ }^{45}$ The Regent did not explain his answer in detail, so the committee members did not know the fact. They were just groping for what really happened.

The construction process was stopped because of the political factors as delivered by Soepeno Hadi. He recalled that in a committee meeting, the Regent, Iswarto, requested consideration to the

\footnotetext{
${ }^{41}$ Samsul Munir Amin, Sejarah Peradaban Islam (Jakarta: Amzah, 2015), pp. 260, 267.

${ }^{42}$ Hasan Asari, Menyingkap Zaman Keemasan Islam (Bandung: Mizan, 1994), pp. 48-66.

${ }^{43}$ Document of the first stone laying procession of Istiqomah mosque

44 Interview with H. Soepeno Hadi on July 13, 2016. He was a committee; This information is corroborated by documentary of the first stone laying photo.

45 Interview with K.H. Mohammad Ridwan on June 29, 2016.
} 
committee to move the mosque to his private property located in Ungaran, but it was not on a strategic roadside. The Regent conveyed the reason that there were other parties which concerned about the construction of the mosque. They were afraid that one day, a group of "Komando Jihad" would appear in front of the church. ${ }^{46}$ The term of "komando jihad" is a negative political stigma against Muslims at that time. ${ }^{47}$

Ahmad Toha also delivered information about the political controversy. At that time, a party proposed to the Governor of Central Java (Soepardjo Rustam) that the location of the mosque should be relocated to the edge of the highway. The information reached to the committee. ${ }^{48}$ During the stagnant controversy of the construction process, Iswarto was promoted as the Resident of Kedu. Setyawan Sadono as the Regional Secretary temporarily held the administration. Mutation also occurred to Mas'an Karno as Secretary of the mosque construction. Iswarto and Mas'an Karno eventually moved from Ungaran to Temanggung. ${ }^{49}$

Controversy on the construction of mosque, according to some young figures, occurred due to four factors. ${ }^{50}$ First, the location of the mosque is unique. The mosque is in front of the church, while the Kristus Raja Church had stood earlier than the mosque. This position of the mosque was still very rare at that time. Second, the position of the mosque was strategic. The Diponegoro road of Ungaran was the only way from Semarang to Solo or Semarang to Yogyakarta. The location of the building on the side of the protocol road certainly invited the attention of the cross-city people who passed. ${ }^{51}$ Third was a

\footnotetext{
${ }^{46}$ Interview with H. Soepeno Hadi on July 13, 2016.

${ }^{47}$ Solahudin, NII sampai JI Salafi Jihadisme di Indonesia (Yogyakarta: Komunitas Bambu, 2011), pp. 81-85.

48 The location is to the northwest of the mosque, approximately 100 meters. Interview with Ahmad Thoha SH, MM, on June 27, 2016.

${ }^{49}$ Interview with Mas'an Karno on August 15, 2016. He is active in praying at Istiqomah mosque, because his house is adjacent to the mosque.

${ }^{50}$ Representation of the young figures such as Ahmad Thoha, SH., Endro Utomo, SE., Drs. Toni Irianto. They were not yet a committee, because of the age factor, but they had witnessed the process of construction and noticed its social phenomenon. Limited discussion on February 12, 2017 at Istiqomah Mosque Hall.

51 Map of the mosque facing the church can be seen on: https://www.google.com/maps/place/Gereja+Katolik+Kristus+Raja+Ungaran/.
} 
monument building plan. This factor could be known from the construction of two-storey and large-sized buildings. ${ }^{52}$ The mosque building would also be equipped by a dome like that of Istiqlal Mosque in Jakarta. ${ }^{53}$ A large domed mosque had never existed in Semarang before. Fourth, the negative stigma to the Muslims' political movement. This was implicating in the government and some communities. In the internal Muslims themselves appeared groups of people that reinforced the negative stigma. These groups declared anti Pancasila and tried to revive the idea of Darul Islam/Tentara Nasional Indonesia (DI/TII). They often perpetrated violence on the name of Islam. Violence took place in various locations in the form of terror to create chaos. The movement was then popularly known as "Komando Jihad". 54

The four factors of controversy are related each other, but the negative stigma towards political Islam becomes more dominant and justify some other factors. Such dominance can be seen in the issues that link the construction of the mosque with the intolerance movement and "Komando Jihad". Soepeno Hadi explained that the negative stigma toward the construction of the mosque was in fact contrary to the reality of thought and life of the foundation's board individually or organizationally. They had no track record of being intolerant and anti Pancasila movement. Their main goal was to build a mosque and to establish a foundation precisely to assist the government in realizing the appreciation and practice of Pancasila and realizing prosperous Indonesian society. ${ }^{55}$

The foundation board got a little trouble to break a negative stigma about Islam and Muslims. They realized that the epicentrum of the stigma was no longer at the local level, but rolled up to the center of power. The New Order rulers at the central level since 1966 had been antagonistic toward Muslims. The government was easily suspicious of the political movement of Muslims. ${ }^{56}$ Ricklefs also stated that in facing

\footnotetext{
${ }^{52}$ Building area is $900 \mathrm{~m}^{2}$.

${ }^{53}$ Interview with Soesmono Martosiswojo, the former regent of Semarang, ex-officio chairman of Istiqomah Foundation period 1979-1985, May 3, 2015.

${ }^{54}$ Solahudin, NII sampai JI, pp. 81-85.

55 Article 4. Notarial Deed of Establishment of Istiqomab Foundation. Notary H. Pandji Surya SH., September 20, 1978.

56 The relationship between Islam and the New Order government is categorized into three phases; Antagonistic, critical, and accommodative reciprocal. An antagonistic
} 
Muslims, the government adopted the Snouck Hurgronje's orientalist political tactic. ${ }^{57}$ Hurgonje, according to Aqib Suminto's analysis, sorted Islam into three categories, namely Islam in a worship field, Islam in a social field, and Islam in politics. In the field of worship, the government gave Muslims independence to carry out their religious teachings as long as it did not interfere its power. In the social field, the government used the prevailing customs to mobilize the people to approach the government. However, in the field of politics, the government explicitly prevented the people from extremism. The enemy of the government was not Islam as a religion (worship), but Islam as a political ideology. ${ }^{58}$ The New Order regime respected Islam as a religious practice in private, but closed the opportunity to become a political force. ${ }^{59}$ The mainstream of political implication is that the government provides assistance to religious institutions that are not indicated by politics. For religious institutions indicated by politics, the government prevents and suppresses its movement. ${ }^{60}$

In the historical context, it was known that there was actually a controversy among the elites of the New Order regimes. Elites at the central level considered that the construction of a mosque was a "political Islam" movement that needed to be evaluated, while the elites at the local level understood it as the realization of a national development plan that should be resolved thoroughly. The regent as the New Order elite at the local level was subject to the central elite. $\mathrm{He}$, as a regent and chairman of the mosque constructional committee, was responsible for the building of the mosque. He had to be responsible for his decision. One of his responsibilities was to offer the transfer of the location of the mosque to his land. However, the committee insisted on rejecting the offer, because the mosque's location was not on the strategic side of the road.

The solution to the problem of mosque construction was finally idled for almost one year. The committee did not have political access

occurred between 1966-1981. Abdul Aziz Taba, Islam dan Negera dalam Politik Orde Baru (Jakarta: Gema Insani Press, 1996), pp. 240-243.

57 M.C. Ricklefs, Sejarab Indonesia Modern 1200-2004, Trans. Satrio Wahono, et.al. (Jakarta: PT Serambi Ilmu Semesta, 2008), p. 559.

58 Aqib Suminto, Politik Islam Hindia Belanda (Jakarta: LP3ES, 1996), pp. 9-10.

${ }^{59}$ Ricklefs, Sejarah Indonesia, p. 559.

${ }^{60}$ M. Rusli Karim, Negara dan Peminggiran Islam Politik. (Yogyakarta: Tiara Wacana, 1999), p. 119. 
to the center of power. Iswarto, the Regent, had been mutated to another area. The central government, on the other hand, has not assigned a new Regent to lead the local government.

The committee should have had an access to the Department of Religious Affairs (now is the Ministry of Religious Affairs), but this agency was not politically the only one holding the role of religious affairs in the 1970s. When religious affairs came into contact with the political sphere, the administering agencies were the National Intelligence Coordinating Agency (BAKIN), the Operation Command for Restoring Security and Order (Kopkamtib), the Special Operations (Opsus), or the Directorate General for Social and Political Affairs at the Ministry of Home Affairs. ${ }^{61}$ These agencies were primarily tasked to overseeing political activities in order to win Golkar. ${ }^{62}$

\section{Approach to Relieve Controversy of the Mosque Construction}

When the position of the regent of Semarang was vacum for almost a year, the Central Java Governor, Soeparjo Roestam commissioned Soesmono Martosiswojo as the Regent of Semarang in early 1980. The governor targeted two achievements to Soesmono, they were to advance Semarang regency and to win Golkar in the 1982 general election. ${ }^{63}$

The target of the Governor to be achieved by the Regent was to implement several policies. Among these policies was to continue the construction of the Istiqomah mosque which had stopped for almost a year. Regent Soesmono argued that almost the same with the former regent's point of view that the indicator of progress in Semarang regency was not only with food self-sufficiency and the arrangement of urban infrastructures, but also religiosity. The Regent hoped that the Istiqomah mosque could become a functional symbol of religiosity toward social problems.

To continue the construction of the mosque, the Regent as the chairman of the board did not only propose funds to the Regional People's Representative Assembly of Semarang, but also applied to the

${ }^{61}$ Ibid.

${ }^{62}$ Ibid., p. 123; Thaba, Islam dan Negara, p. 207.

${ }^{63}$ Special Operations is an intelligence agency under the Army Staff Command and Golkar Election Victory Team. In the early of the '70s, there were two of the most active agencies, Opsus led by Ali Moertopo (kebatinan leader) and Kopkamtib held by Sudomo (a Christian). See Thaba, Islam dan Negara, p. 207. 
Minister of Religious Affairs (H. Alamsjah Ratu Perwiranegara). ${ }^{64}$ The Minister of Religious Affairs approved the request and assigned the Directorate General of Islamic Community Development and Hajj Affairs to submit the fund. The Regent received the fund symbolically for twenty million Rupiahs on May 23, 1981.65

The fund from the Ministry of Religious Affairs was financially meaningful to the foundation and political atmosphere. The financial aspect could be seen easily from the increase of the fund. The political aspect could be seen from the historical context of the Minister of Religious Affairs under the power of the New Order. First, the Minister of Religious Affairs at that time was persistently persuading the Muslims to be willing to accept the government's Program of the Appreciation and Practice of Pancasila (P4).66 Istigomah foundation mentioned the program as one of the objectives "to assist the government in realizing the appreciation and practice of Pancasila". ${ }^{67}$ Second, the Minister of Religious Affairs at that time was strengthening the fabric of harmony between religious believers through the forum of "Inter-Ummah Deliberation Means". ${ }^{68}$ In the context of the harmony program, the plan to build a mosque in front of the church was an opportunity to add a new symbol of harmony among religious believers in Indonesia. Therefore, the Minister of Religious Affairs decided to assist the construction of the mosque, not to prevent, divert or leave it abandoned.

\footnotetext{
${ }^{64}$ He served as Minister of Religious Affairs since March 29, 1978 until March 19, 1983. The Minister of Religious Affairs was Prof. Drs. Dr. HA. Mukti Ali (September 6, 1971 to March 29, 1978). See Panitia Penyusun Buku Kenang-Kenangan IAIN Walisongo, Kenangan Dwi Dasawarsa LAIN Semarang (Semarang: IAIN Walisongo, 1990), p. 28.

65 The Regent of Semarang accompanied by Head of Department of Religious Affairs of Semarang, the committee, and related officials. Documentation of submission of fund assistance from Bimas Islam and Haij of the Department of Religious Affairs of the Republic of Indonesia.

${ }^{66}$ Karim, Negara dan Peminggiran, p. 124.

${ }^{67}$ Notarial Deed of establishment of Istiqomah foundation, Notary H. Pandji Surya SH., Notary in Semarang Jalan Let. Jend. M.T. Haryono No. 515, Copy, September 28, 1978, Number 6.

${ }^{68}$ H. Alamsyah Ratu Perwiranegara, "Wadah Musyawarah Antar Umat Beragama di dalam Negara Pancasila," Dialog, No. 9 (October 1980), pp. 3-5. The facility was inaugurated on June 30 1980. Prior to 1980, the program was named "religious harmony counselling".
} 
On political perspective, the Ministry of Religious Affairs aid increased the confidence of the foundation board. There were two reasons for this self-confidence. First, H. Alamsjah Ratu Perwiranegara was considered a "strong man" in the New Order politics. Four predicates attached to Alamsyah; as a Muslim santri, a minister, an army general, and a "close figure" to President Soeharto. ${ }^{9}$ Second, the government bureaucracy was then operationalized centrally by the military. ${ }^{70}$ In this case, H. Alamsjah Ratu Perwiranegara was a member of Indonesian National Army with the rank Lieutenant General. ${ }^{71}$

Although the process of construction had been supported by the Minister of Religious Affairs, the problem of controversy still occurred. For example, the delegation of the Archdiocese of Semarang came to the Regent to object to the construction of the Istiqomah Mosque. The Regent responded that the adjacent location of the mosque to the church is analogous to people of different religions perform prayers in one room. They pray in one room without any partition. The habit has been running in Indonesia and no one has ever questioned about it. Therefore, the construction of a mosque in front of a church need not be faulted, moreover the location of the church and the mosque is still separated by the highway. ${ }^{72}$

In the process of construction there were still many problems that occurred, but not all are written in detail in this research. For example, problem solving over the large budgets, ${ }^{73}$ the job partners, ${ }^{74}$ and the

69 Panitia Penyusun Buku Kenang-Kenangan IAIN Walisongo, Kenangan Dwi Dasawarsa, p. 29.

70 Thaba, Islam dan Negara, p. 188.

${ }^{71}$ Panitia Penyusun Buku Kenang-Kenangan IAIN Walisongo, Kenangan Dwi dasawarsa, p. 28.

72 Interview with Soesmono Martosiswojo, the former regent of Semarang, ex-officio chairman of Istiqomah Foundation period 1979-1985, May 3, 2015.

73 The Foundation raised the participation of funds from Muslims, especially civil servants in Semarang regency. Interview with Mastur Irfan on June 6, 2016. He was a former secretary deputy of Golkar in the early of the ' $80 \mathrm{~s}$.

${ }^{74}$ The committee entrusted the process of building a mosque to Budi Santosa from Semarang, as he was considered professional and has a dedicative attitude. (Interview with the former regent of Semarang, ex-officio chairman of Istiqomah Foundation period 1979-1985, Soesmono Martosiswojo, May 3, 2015). Budi Santoso has led the company Suara Merdeka since 11 February 1982-2010. (http://siapa.co.id/2015/05/01/siapa-pendiri-harian-suara-merdeka/. Accessed on April 12, 2017). 
internal frictions of officials. ${ }^{75}$ The construction of the mosque continued until the time of its inauguration arrived on Sunday, March 14, 1982, exactly before the time of dlubur prayer. ${ }^{76}$ The opening ceremony began with the recitation of the Holy Qur'an, speeches, ribbon cuts, and the call to prayer for the first time. ${ }^{77}$ The official who signed the the inscription was the Minister of Home Affairs, Amir Machmud. ${ }^{78}$ He was coming to inaugurate the mosque after attending political events in other areas. ${ }^{79}$

Amir Machmud's presence had a significant political influence on the foundation board, as he was also a strong man in the New Order regime. Beside being a Minister of Home Affairs, Amir Machmud also served as the Chairman of the General Election Institute (Lembaga Pemilihan Umum). He was elected as a chairman of the People's Consultative Assembly (Majelis Permusyawaratan Rakyat) in 1982 and concurrently served as chairman of the House of Representatives.

Thus, there were two New Order figures who appeared openly in the construction of Istiqomah mosque, namely H. Alamsjah Ratuperwira Negara and Amir Machmud. The two ministers were militarybackground, as a General, played an important role in Golkar's victory, and close to President Suharto. ${ }^{80}$ The support of the two ministers reinforced the public's perception that the Istigomah mosque is a government mosque. The control on the mosque was on the hand of the Regent. The government also allocated annual subsidy funds to support its operational costs. There were also some people who called it as Istiqomah mosque as a district mosque because of its strategic location in the district capital. The mosque was managed by the local leaders and local-leading scholars. ${ }^{81}$

\footnotetext{
${ }^{75}$ Harsja W. Bachtiar, "The Religion of Java: Sebuah Komentar," within Clifford Geertz, Abangan, Santri, Priyayi dalam Masyarakat Jawa (Jakarta: Pustaka Jaya, 1981), pp. 521-551.

${ }^{76}$ Inscription of Inauguration of Istiqomah Mosque.

${ }^{77}$ Interview with Nurul Fadlilah's mother, daughter of H. Muhammad Ja'farin Ahmad, October 5, 2016.

${ }^{78}$ Inscription of Inauguration of Istiqomah Mosque.

${ }^{79}$ Interview with Mastur Irfan on May 23, 2016.

${ }^{80}$ Karim, Negara dan Peminggiran, p. 81.

${ }^{81}$ H. Amidhan and Usep Fathudin, Pedoman Pembinaan Masjid, Jakarta, Proyek Pembinaan Sarana Keagamaan Islam (Jakarta: Ditjen Bimas Islam dan Urusan Haji, Departemen Agama, 1981/1982), p. 130.
} 
Building Tolerance: Implementation and Socialization of Moderate Islamic Principles in the Mosque's Management

The inauguration of the mosque created a new atmosphere for the surrounding environment. For example, at $12 \mathrm{am}$, people could hear the call to prayer, whereas in the days before, they had only heard the sound of church's bell striking. The same atmosphere took place in the evening and in the morning. The environment, which was initially only crowded with the school children, the situation gradually became crowded with many people, because the mosque also became a rest area for the travelers. In addition, the surrounding people were also coming to the mosque to worship or just enjoy the fresh garden of the mosque. 82

It seems that the new atmosphere did not pose problem in interreligious life. There was no record of violence from the mosque to the church or vice-versa. Father A. Hantara Pr, who worked in the Kristus Raja Church had a good communication to some of the mosque activists. Ahmad Thoha, as a representation of the younger generation claimed to often communicate directly to A. Hantara Pr. He also often visited his residence in the church's complex. A harmonious atmosphere was created, because the church did not involve Muslims in its activities, nor did the mosque involve Catholics in its activities. Church and mosque organized ritual and non-ritual activities for the internal circle of their own people. ${ }^{83}$ The harmonious condition between the mosque and the church could also be seen on the mosque's ground. The church congregants parked their vehicles in the mosque's yard as they were doing worships. The mosque's congregants also parked their vehicles in the church's yard when they had certain events.

Harmonious atmosphere also occurred within the internal mosque's boards. They resort to moderate way of worship. For example, the call for prayer (adhan) of the Friday prayer at Istigomah Mosque is done twice, as it has been applied in the NU communities, but in practice, it is similar to that of the Friday prayer in the Muhammadiyah communities. Muadzin (the caller) for Friday prayer is housed in the sound system operator room on the $2^{\text {nd }}$ floor. Muadin

82 Interview with Endro Utomo on March 1, 2017. He is a former teenager activist of Istiqomah Masjid.

83 Interview with Ahmad Thoha on March 1, 2017. 
does not stand in front of the preacher as it happens in the NU communities. Moderate Islamic practices also occurs in the tarawih and witir prayers in Ramadan. The tarawih and witir prayers are performed in eleven raka'at as practiced in the Muhammadiyah communities. Another example is that after the call to prayer has completed, the muadzin does not proclaim such a praise in the NU communities. They only get used to praying sunnah, as in the Muhammadiyah communities. The takbir sentences in the holidays are similar to those of the NU communities, ${ }^{84}$ but the prayers are performed in the mosque's yard as it does in the Muhammadiyah communities. For the determination of the Qurban and Eid al-Fitr holiday, mosque officials agreed to follow the government's decision. The preachers and priests of Friday prayers are also a combination between NU and Muhammadiyah scholars. ${ }^{85}$

From the past until now, the imam of the mosque often read the chapter of al-Kafirun and al-Ikblas in their prayers. These two chapters of the Qur'an have a contextual meaning for the mosque. Chapter alIkblas affirms about the oneness of God, He does not have children nor He is begotten by anyone. Theologically, the contents of chapter al-Ikblas certainly contradict to the belief of the Church. However, the chapter al-Kafirun affirms the principle of لكم دينكم ولى دين (for you your religion and for me my religion). Living in harmony according to each theological principle. 86

The moderate Islamic thought does not only establish a harmonious attitude and behavior in the internal mosque, but it can also harmonize the influence of the church. In the internal context of the mosque, they meet in the framework of Indonesia, Pancasila, and national development. In the external context of the mosque, they meet to the church in the framework of Indonesia, Pancasila, and national development.

${ }^{84}$ The NU communities read takbir three times;

$$
\text { الله اكبر الله اكبر الله اكبر لااله الا الله والله اكبر الله اكبر وللله الحمد }
$$

while the Muhammadiyyah communities read takbir twice;

$$
\text { الله اكبر الله اكبر لااله الا الله والله اكبر الله اكبر وللله الحمد }
$$

85 Interview with Latif on May 21, 2016. He is an operational employee of Istiqomah mosque since 1987 until now.

86 Experience for several years conducting prayer at Istiqomah mosque and interview with the Imam of Istiqomah Mosque. 
The moderate Islamic principles are continuously socialized to the Istiqomah mosque's younger generations. Hendro Utomo said that the Istiqomah mosque's younger generation boards are heterogeneous in terms of educational and religious background. Beside they are active in the Istiqomah mosque, they are also active on campus and other Islamic organizations. They also bring their activities outside into the mosque such as the Intensive Islamic Studies Forum (FOSI), the Islamic Basic Values (PNDI), and the temporary Islamic boarding school program (pesantren kilat). These activities gain serious attention from the teenagers.

The Islamic studies, which are held by the Istigomah mosque's young generation boards, from the aspect of name, pattern, and movement, have potential elements to counter to the government's policies. For example, some mobilizers from FOSI and PNDI are the activists of "HMI MPO". 87 The name of "pesantren kilat" according to Solahudin also has a genealogical link to the Darul Islam movement. ${ }^{88}$ The foundation boards actually know about the political sensitivity of the Istiqomah mosque's youth, but they still provide space for their actualization in the mosque. They believe that their activities in the mosque are more observable than in other places. One of the ways the board monitor youth activities is to control the guest speakers. The foundation boards also often involve themselves as one of the speakers. ${ }^{89}$

Although the mosque youth activities run intensively, but it did not create friction to the church youths. Individual communication between mosque and church officials remained intertwined. The communication was well established by the development of political attitudes of the government against Muslims. The government changed its political stance, from antagonistic to critical reciprocity. ${ }^{90}$ The principles of moderate Islam are also socialized to the elderly through the Islamic studies on every Sunday morning. They came from several villages in Ungaran and some surrounding villages. The audiences are increasing from time to time. The number of audiences in 2016 reached an average of 1250 people. The preachers are mostly

\footnotetext{
${ }^{87}$ Thaba, Islam dan Negara, pp. 262-274.

88 Solahudin, NII sampai JI, pp. 170-171.

${ }^{89}$ Interview with Toni Irianto on March 3, 2017.

90 Thaba, Islam dan Negara, p. 262.
} 
the "neo modernist" scholars of Ungaran and its surroundings. ${ }^{91}$ They convey the Islamic teachings from the aspects of Sunni Ash'ari theology, Shafi'iyyah Islamic law, and Sufism codes of conduct. Each speaker presents the topic of the discussion according to his own taste, so the curriculum looks less systemic.

The committee of the Islamic studies also often invited the Regent to give a welcoming speech before the core agenda. The content of the Regent's welcoming speech always referred to the government's vision for the Muslims. As a regional leader, the Regent also appealed to the Muslim community to take care for interfaith harmony..$^{92}$

The preachers give their speech not just to give information (to inform) about Islamic teachings, but also to strengthen the belief of the audience (to strengthen belief). Some preachers also seek to change the confidence of the audience in order to become purer, more straight, and modern.

Among the speakers, there is only one person who consistently uses the manuscript method. He reads the Islamic book entitled Riyadl Al-salibin then translates and describes it to the audiences. Other speakers tend to use a framework translation method (improptu) and a rote method (memorital) ${ }^{93}$ with any humors to make the audience be fresh and happy. Evidently the educative humors are becoming the main attraction for the audience.

The media used by the preachers was originally just a loudspeaker. However, after the participants booming outside the hall, the committee installed the screen in some corners of the terrace. Once, the volume of the loudspeaker was so strong that it was heard up to the church, where there was a worship service. On the occasion, the committee switched down the volume to maintain comfort.

When the Islamic study ended, there was a new scene in front of the Istiqomah mosque and the church. Audiences from the mosque and from the church are coming out at the same time. The differences was

\footnotetext{
${ }^{91}$ Muhaimin, Pemikiran dan Aktualisasi Pengembangan Pendidikan Islam (Jakarta: Rajawali Press, 2011), pp. 21-25.

${ }^{92}$ For example, the regent's remarks during the commemoration of Isra' and Mi'raj of the Prophet Muhammad on April 24, 2017 at the Istiqomah Mosque Hall of Ungaran.

${ }^{93}$ Helena Olii, Public Speaking (Jakarta: Indeks, 2010), pp. 46-49.
} 
that the audiences from the mosque carried the Holy Qur'an while the audiences from the Church carried the Bible. ${ }^{94}$

Although they come from different places of worship and hear different lectures, they remain peaceful when they meet on the sidewalk and highway. There was no interruption and reproach among them. One of the most amazing things was the Church's congregants and the mosque's greet each other. Even, those who are returning in the same direction are also taking the same public transportation. In a public transportation there has never been any debate or commotion. On the other hands, polices who stationed in front of mosque and church concentrate on dealing with the traffics. These conditions show that the inter-religious harmony in Ungaran is reflected in the social interaction of each followers to keep harmony among them.

\section{Balancing the Plurality of Educational Institutions}

After Soesmono Martosiswojo's tenure as a Regent of Ungaran ended in 1985, Sarjono was appointed as his successor. Sarjono only served two years then he was replaced by Hartomo in 1987. Like the previous regents, Hartomo became the ex-officio chairman of the foundation.

The change of chairman was followed by the change of management. 95 The new foundation's boards continued their former boards' programs and continued doing innovations. The initial innovation was balancing the variant of education in Ungaran by establishing Islamic Kindergartens and Elementary School.

The idea of establishing Islamic education was driven by the concern of the foundation's board of the inequality of the formal educational institutions for Muslim children in Ungaran. Islamic

\footnotetext{
${ }^{94}$ They shop in the Istiqomah mosque's yard. Every Sunday morning this place becomes something like a "sudden market" for cloths, books, perfume, and food.

95 The names of the new chairmen at the Istiqomah Foundation are H. Mohammad Amin Hambali, Wahjudi, Sukaemi. Srijanto, Soempeno, and Achmad Makin Basri hold the secretaries. Muhammad Ridwan Muhtar and Mubasir hold the treasurer. The ranks of the board members were Tawabul, H. Muhammad Dja'farin Achmad, Muhammad zaenuddin Abdoellah, Kahar Samrozi, and dr. Sentot D. Wardoyo. Notarial Deed of the Foundation was made by Achmad Dimyati, S.H. In Ambarawa, Semarang on February 1, 1989. The basis for the amendment of the Notarial Deed was the decision of the plenary meeting of the Istiqomah Mosque Foundation Board of October 13, 1988. The only changed in article 1 concerning with the name and article 2 on the basis.
} 
Kindergartens were only two institutions ${ }^{96}$ and Islamic Elementary School had not existed yet. Many Muslim children are studying in Catholic educational institutions, such as Mardi Rabayu Kindergarten, Mardi Rabayu Elementary School, ${ }^{77}$ Kanisius Kindergarten, and Kanisius Elementary School. ${ }^{98}$ There were also many who studied in Christian Elementary School. Madrasah educational institutions stood in villages, ${ }^{99}$ but the urban of the Muslims middle-class were less interested in this type of educational institution.

The boards of the foundation wished that Istiqomah mosque did not only exist with some of the mosque's activities, but also formal education activities for children. Islamic educational institutions in the mosque could be an alternative for Muslims in Ungaran and its surrounding areas. The desire grew stronger after one of the foundation's boards observed the atmosphere of $A l-A z h a r$ mosque in Jakarta. ${ }^{100}$

The desire of the foundation's board was realized by utilizing the mosque hall for the education of Raudatul Athfal (Kindergarten). The interest of the Ungaran communities was great enough to the institution, so that the foundation's board was trying to prepare a new infrastructure in the east of the mosque. This infrastructure was expected to work for kindergarten's activities in accordance with the vision of the foundation.

The construction of new infrastructure was completed in 1990, but the foundation boards changed their mind. In 1991, the building was functioned for Istiqomah Islamic Elementary School. In the perspective of the foundation boards, educational institutions for early childhood and Elementary School in the mosque's environment did not only have good prospects for Muslims in Ungaran, but also could balance the plurality and strengthen harmony.

Good prospects for Islamic Kindergartens and Elementary Schools are based on several conditions. First, the majority of the population of Ungaran and its surroundings are Muslims. This

\footnotetext{
96 Perwanida I Kindergarten in Kauman and Al-Qobul Kindergarten in Muneng Sidomulyo.

${ }^{97}$ Interview with Toni Irianto on April 12, 2017.

${ }^{98}$ Ibid.

${ }^{99}$ Like Nyatnyono, Lerep, Gedang Anak, and Kalirejo villages.

100 Interview with Mohammmad Ridwan on July 12, 2016.
} 
demographic condition is the main capital for the future of the schools. Second, Ungaran at that time has started to become an urban area. ${ }^{101}$ Immigrants in Ungaran are not only those who work in Ungaran, but also in Semarang. The pace of urbanization and migration has prompted entrepreneurs to develop housing complexes in Ungaran, thus forming a large housing community. 102 Some residents of housing and Muslim community want their children study in qualified and affordable Islamic educational institutions.

Third, the vision of the Istiqomah foundation is moderate, allowing Muslims from diverse circles to accept its presence. The moderate character has its own appeal, because Muslims at that time consisted of several groups and professions, such as businessmen, company employees, traders, civil servants, army, police, and farmers. Fourth, the school plan is focused on primary school level. This reason is relevant to the development of urban awareness of the urgency of religious education for children. They hope that their children are not only clever in the knowledge and skill aspect, but also have a strong nationality and Islamic personality. Fifth, the name Istiqomah mosque has become popular among Muslims in Ungaran and its surroundings. The popularity is also boosted by the guarantee of the management of foundation from among the bureaucrats. Sixth, the location of Istiqomah schools are strategic from various directions, so that they are easy to reach.

In accordance with the foundation boards prediction, Istiqomah Kindergarten appealed Muslim communities. ${ }^{103}$ The students came from residential complexes, army dormitories, and several areas around the Istiqomah Mosque. ${ }^{104}$ Their parents' profession was also vary, such

101 Budyapranata, Buku Kenangan, p. 10.

102 For example, housing complex of Sidosari, Sebantengan, Perikanan, Perumda, Niti Buana, Selamarta, Korpri, PHB, Mapagan, and PLN. The residents of the complexes are generally varied, except Sidosari, Perumda, and Korpri (the majority are the civil servants).

103 Istiqomah Kindergarten was formerly named by Perwanida II Kindergarten (the main book document of Istiqomah Kindergarten in 1989/ 90).

104 For example, students named Hendro Prasetyo and Arif Rahman Hakim are located at Jalan Diponegoro 227 Ungaran, Fendi Hermawan from PLN Complex, Deni Saputra from SDLB housing complex, Totok Setiawan at TNI Dormitory, Gigih Ori Bowo in Perikanan housing complex, Rinto Nugroho and M. Arif Wardana from Jalan Slamet Riyadi, Feni Laga from Dliwang, Jihaduddin FA from Sebantengan 
as bank employees, company workers, civil servants, electricity workers (PLN), teachers, lecturers, and businessmen. ${ }^{105}$ The number of Istiqomah Kindergarten students reached up to 2000 as follows. ${ }^{106}$

Table 1. Number of Students of Istiqomah kindegarten in 1988-2000

\begin{tabular}{llcc}
\hline \multirow{2}{*}{ Year } & \multicolumn{2}{c}{ Student } & Total \\
\cline { 2 - 4 } & \multicolumn{2}{c}{ Male } & \multicolumn{2}{c}{ Female } & \\
\hline $1988 / 1989$ & 13 & 16 & 29 \\
$1989 / 1990$ & 31 & 29 & 60 \\
$1990 / 1991$ & 49 & 45 & 94 \\
$1991 / 1992$ & 51 & 43 & 94 \\
$1992 / 1993$ & 71 & 54 & 125 \\
$1993 / 1994$ & 73 & 52 & 125 \\
$1994 / 1995$ & 63 & 74 & 137 \\
$1995 / 1996$ & 48 & 58 & 106 \\
$1996 / 1997$ & 88 & 90 & 178 \\
$1997 / 1998$ & 113 & 96 & 209 \\
$1998 / 1999$ & 116 & 109 & 225 \\
$1999 / 2000$ & 133 & 113 & 246 \\
\hline
\end{tabular}

Istiqomah Islamic Elementary School also obtained legality from the Ministry of Education and Culture and sympathy of Muslims. ${ }^{107}$ Students came from residential complexes, dormitories, and some villages around the Istiqomah mosque. Schools are also growing steadily. Number of students were up to 2000 as follows. ${ }^{108}$

Table 2. Number of Students of Istigomah Elementary School in 1988-2000

\begin{tabular}{ccccc}
\hline \multirow{2}{*}{ Year } & \multicolumn{2}{c}{ Student } & \multirow{2}{*}{ Total } \\
\cline { 2 - 4 } & \multicolumn{2}{c}{ Male } & Female & \\
\hline $1991 / 1992$ & 18 & 15 & 33 \\
$1992 / 1993$ & 14 & 16 & 30 \\
\hline
\end{tabular}

housing, Nuraeni from Blanten Hamlet, Adi Merita from Perumda housing complex. See the main book document of Istiqomah Kindergarten of Ungaran in 1988/1989.

105 Ibid.

106 The main book document of Istiqomah Kindergarten of Ungaran in 1999/2000.

107 School Statistic Number for the Istiqomah Islamic Elementary School is 104032214068.

108 The Istiqomah Islamic School's Monthly Report Book in 1999/2000. 


\begin{tabular}{|c|c|c|c|}
\hline \multirow[t]{2}{*}{ Year } & \multicolumn{2}{|c|}{ Student } & \multirow[t]{2}{*}{ Total } \\
\hline & & & \\
\hline $1993 / 1994$ & 18 & 12 & 30 \\
\hline 1994/ 1995 & 19 & 13 & 31 \\
\hline $1995 / 1996$ & 18 & 13 & 31 \\
\hline 1996/ 1997 & 18 & 11 & 29 \\
\hline $1997 / 1998$ & 25 & 29 & 54 \\
\hline 1998/ 1999 & 28 & 27 & 55 \\
\hline $1999 / 2000$ & 35 & 20 & 55 \\
\hline
\end{tabular}

The presence of Istiqomah Kindergarten added a balanced plurality of educational institutions in Ungaran. It was because before the Istiqomah Kindergarten, there had been an Islamic Tunas Harapan and a catholic Mardi Rabayu Kindergarten around the Kristus Raja Church and Istiqomah Mosque. A similar phenomenon also occurred in the Elementary School. At the beginning, in Ungaran, there were only State Elementary School, Catholic Elementary School, and Christian Elementary School. Lately, there was Istiqomah Elementary School.

The addition in variant of the Kindergarten and elementary schools has a specific meaning in building inter-religious harmony. As it is known that the population of Ungaran increases due to migration and urbanization. Some of them are santri and educated Muslims. This condition encourages the establishment of an Islamic educational institution. The presence of Istiqomah Kindergarten and Elementary School did not only broaden the choice for Muslims to send their children to school, but also narrow the chances of friction among the different religion followers.

\section{Disseminating the Moderate Islamic Leadership}

Reform had changed the order of foundation throughout Indonesia. Law No. 22 year 1999 article 48 (a) prohibits regional leader from "participating in a company, whether it is a private or a stateowned, or in a foundation of any fields". ${ }^{109}$ This regulation encouraged the regent of Semarang, Bambang Guritno, to change the management of Istiqomah Foundation to comply with the Law and accelerate progress.

The first four years after 1999 there were unstable conditions in the foundation's leadership. At the beginning, the chairman of the

${ }^{109}$ Undang-undang Otonomi Daerah (1999), p. 25. 
foundation was Soendoro, but two years later (2001) it was assigned to his deputy chairman, Masykur (38 years). The change of chairman was solely due to internal dynamic and not influenced by any external factor. Soendoro was known as a busy businessman, while Masykur was known as a person who close to a religious organization.

Masykur's leadership lasted for four years (2001-2005). After that it switched to his deputy, Ahmad Thoha (39 years). The change of chairman happened because Masykur was getting busy with his business. Ahmad Thoha was a representation of a moderate santri. He has grown in Istiqomah mosque since he was a teenager, so that he knew the dynamics of the mosque's leadership better. When Ahmad Thoha became one of boards of the mosque's youth he often communicated to Father A. Hantara Pr, Father Parokhi at Kristus Raja Church. ${ }^{110}$

The character of plurality and moderate are also maintained within the foundation's boards composition. This foundation's boards consist of not only NU and Muhammadiyah activists, but also bureaucrats. They know and respect each other's religious leanings. This character is manifested in the spirit of the board to continue the worship practices of the previous leaders.

The regeneration of the foundation's leadership was corroborated by the Notarial Deed and the Decree of the Minister of Law and Human Rights of the Republic of Indonesia in 2015.111 The leadership regeneration, since the reformation era, has made some progresses. Among them are: first, the new leadership should be able to take care of the internal Muslim harmony and among interfaith believers. In the aspect of internal harmony of the religious community, Istigomah mosque is often used for meeting by the leaders of Islamic organizations in Semarang ${ }^{112}$. They met incidentally to deliberate on some national agenda. Moreover, the mosque is also used for training for Islamic students from campuses around Ungaran. ${ }^{113}$

\footnotetext{
110 Interview with Ahmad Thoha on April 21, 2016.

111 Notarial Deed No. 55 dated December 29, 2015, drawn up by notary Rika Budi Antawati, SH., M.Kn. Decree of the Minister of Justice and Human Rights of the Republic of Indonesia Number AHU-0033995.AH.01.04. Year 2015.

112 For example, NU, Muhammadiyah, The Qur'anic Commentary Assembly (MTA), Indonesian Islamic Da'wah Institute (LDII), Islamic Studies Groups, Indonesian Mosque Council (DMI), Association of Indonesian Haij Brotherhood (IPHI).

113 Interview with Latif on April 28, 2017.
} 
The presence of the leaders from the Islamic organizations and Islamic students in the mosque did not raise a good relation between mosque and church. It could precisely strengthen the harmony. For example, the church's boards visit the mosque's boards to introduce a new church's leaders. ${ }^{114}$ The mosque also reminded the church's leaders to really strengthen harmony and not otherwise. ${ }^{115}$ Second, the new leadership could maintain a balance of plurality in the field of education. As had been explained before that an Islamic Kindergarten and Elementary School could play as a balancing the plurality of education in Semarang. The balance has developed since the early of the "90s until now. This development of the physical aspect had started from the era of Masykur (2001). Infrastructures and educational facilities are increasing, so that Islamic Kindergarten and Elementary School can accommodate more students. Beside the number of teachers and employees also increases, the learning process also increases its quality. The improvement of quality of the Istiqomah Islamic education inspired other Muslims to establish Islamic Kindergarten and Islamic Elementary Schools in Ungaran.

\section{Revealing the Mosque's Disproportionate Performance to the Church}

Since 2007, the infrastructure of Ungaran has grown up around the Istiqomah mosque. The buildings on the right and left of the mosque are built in 2 floors. As a result, the view to the mosque's dome is getting obstructed. It was different with in the 1970s that the dome of the mosque was visible from distance.

The building of the mosque that seems to be drowning invites the attention of many people. Moreover, this mosque has long been a rest area. Those who will visit the mosque only recognize it from the traffic signs on the roadside. On the other hand, the building of the church is changed increasingly with the symbol of the towering cross. This condition is in contrast to the dome of the mosque, the symbol of the towering cross of the church is already visible from distance. This

\footnotetext{
114 The document is a guest book of Istiqomah Mosque.

115 The commemoration of the mosque's board to the church's leader occurred in May 2015. The church invited the leaders of Muslims and the poor to break their fast together. It was placed in the church. The mosque reminded the church's authorities to reconsider the agenda or modify the event so that there would be no misperception with Muslims. Interview with Zaenal Abidin on March 17, 2017.
} 
phenomenon has attracted criticisms from some Muslims. Among them stated that the symbol of harmony is less balanced.

Those who criticize the mosque's building suggest that it should be elevated, so the dome is easily recognizable from distance. Those who have concerned to religious harmony also advise the mosque's dome to be re-displayed so that it is balanced with the symbol of the towering cross of the church. The internal Istigomah foundation is also thinking to develop educational infrastructures, because the number of students are increasing continuously.

Suggestions from various parties are accepted by the board of the foundations because they are relevant to the internal needs. The board plans to add the infrastructures in the north of the mosque. Construction of a 4-storey building with a dome roof model. The building has three functions. First, revealing the building of the mosque that is drowned because of the buildings around the mosque. Second, balancing the symbols of the Church and the Mosque. Third, adding new infrastructure for the needs of Kindergarten and Elementary School students, and the foundation management. In 2012, the process of reconstruction was begun.

The cost of mosque construction is taken entirely from the foundation. The source of the fund comes from the fees of the Istiqomah Kindergarten and Islamic Elementary School students. The Muslim communities also participated in the reconstruction since it is considered a moral responsibility. One thing to note here is that no fund comes from the government or foreign countries. The new building has completed in 2014.

\section{Conclusion}

The principles of moderate Islam, as shown by Muslim scholars particularly from Islamic organization like NU and Muhammadiyah, play a significant role in the process of reconstruction of the Istiqomah Mosque in Ungaran, Central Java, Indonesia. They do not contrast Islam and Pancasila, but bring them together proportionately. However, the role and contribution of the government also play an important role. Some purposes of the construction, as the rulers and scholars agreed, are to balance the national development, to prevent the influence of the Indonesian Communist Party, and to create a symbol of tolerance. In the process of construction, there were some controversies among the committee and some of the New Order's 
political elites as well as religious leaders of the church. Those who countered the mosque stigmatized that it was a Political Islam, so that they tried to stop or divert it. The controversy has waned after the New Order's elite, H. Alamsyah Ratuperwira, supported the construction of the mosque financially and politically. Support was obtained because the committee has shown a commitment to develop moderate Islam. Another reason was that the Istiqomah Mosque could enrich the symbol of tolerance among religious believers in Indonesia. The mosque embraces new ways of implementing moderate Islamic principles, socializing and balancing the plurality of religions within the society, establishing educational institutions, and renovating the physical building of the mosque.]

\section{References}

\section{Books and Articles}

Amidhan, H. and Usep Fathudin. Pedoman Pembinaan Masjid, Jakarta, Proyek Pembinaan Sarana Keagamaan Islam. Jakarta: Ditjen Bimas Islam dan Urusan Haji Departemen Agama, 1981/1982.

Amin, Samsul Munir. Sejarah Peradaban Islam. Jakarta: Amzah, 2015.

Asari, Hasan. Zaman Keemasan Islam: Kajian atas Lembaga-lembaga Pendidikan. Bandung: Mizan, 1995.

Bachtiar, Harsja W. "The Religion of Java: Sebuah Komentar." Clifford Geertz, Abangan, Santri, Priyayi dalam Masyarakat Jawa. Jakarta: Pustaka Jaya, 1981.

Bloom, Jonathan M. and T. W. Gaehtgens. "Mosque Towers and Church Towers in Early Medieval Spain," (1993) http://www.openbibart.fr/item/display/10068/1077878. accessed on 7 Juni 2017.

Budyapranata, Rm. Al., et.al. Buku Kenangan Peringatan 64 Tabun Gereja Kristus Raja Ungaran. Ungaran: Panitia HUT Paroki, 1997.

Departemen Penerangan RI. Lampiran Keputusan Presiden RI Nomor 11 tabun 1974 tentang Rencana Pembangunan Lima Tabun Kedua (1974/75-1978/79). Vol. I. Jakarta: Departemen Penerangan RI, 1974. 
- Lampiran Keputusan Presiden RI Nomor 11 tahun 1974 tentang Rencana Pembangunan Lima Tabun Kedua (1974/75-1978/79). Vol. II. Jakarta: Departemen Penerangan RI, 1974.

-- Lampiran Keputusan Presiden RI Nomor 11 tabun 1974 tentang Rencana Pembangunan Lima Tabun Kedua (1974/75-1978/79). Vol. III. Jakarta: Departemen Penerangan RI, 1974.

Griffith, Sidney H. "the church in the shadow of the mosque:Christians and muslims in the world of Islam." Religious Studies Review, 35, 2 (2009).

Harris, Julie A. "Mosque to Church Conversions in the Spanish Reconquest." Medieval Encounters 3 (1997).

Kuntowijoyo. Penjelasan Sejarah. Yogyakarta: Tiara Wacana, 2008.

Karim, M. Rusli. Negara dan Peminggiran Islam Politik. Yogyakarta: Tiara Wacana, 1999.

Khoury, Nuha N.N. "The meaning of the great mosque of cordoba in the tenth century." Muqarnas 13 (1996).

Loughlin, Seán Mc “The Mosque-Centre, Community-Mosque: MultiFunctions, Funding and the Reconstruction of Islam in Bradford." Scottish Journal of Religious Studies, 19, (1998).

Maesur, Sidqon. "Kafakuman Masjid Walisongo Lempuyangan yang Berdampingan dengan Gereja Kristen Jawa (GKJ) di Dusun Lempuyangan, Desa Timpik, Kecamatan Susukan, Kabupaten Semarang Jawa Tengah.” Research report. Salatiga: Pusat Penelitian dan Pengabdian Masyarakat (P3M) Sekolah Tinggi Agama Islam Negeri (STAIN) Salatiga, 2014.

Minarno, Santoso. "Strategi PNI dalam memenangkan pemilihan umum 1955 di Jawa Tengah." Unpublished bachelor thesis. Semarang: Program Studi Ilmu Sejarah Jurusan Sejarah Fakultas Ilmu Sosial Universitas Negeri Semarang, 2011.

Muhaimin. Pemikiran dan Aktualisasi Pengembangan Pendidikan Islam. Jakarta: Rajawali Press, 2011.

Olii, Helena. Public Speaking. Jakarta: Indeks, 2010.

Panitia Penyusun Buku Kenang-Kenangan IAIN Walisongo. Kenangan Dwi Dasawarsa LAIN Semarang. Semarang: IAIN Walisongo, 1990. 
Perwiranegara, H. Alamsyah Ratu. "Wadah Musyawarah Antar Umat Beragama di dalam Negara Pancasila." Dialog 9 (October 1980).

Ricklefs, M.C. Sejarah Indonesia Modern 1200-2004, Trans. Satrio Wahono, et.al. Jakarta: PT Serambi Ilmu Semesta, 2008.

Saerozi, Muh. "Kebijakan Pendirian Masjid dan Gereja di Indonesia (1511-2007)." Jurnal Miqot, Vol. XXXI, 2 (2007).

Solahudin. NII sampai JI Salafi Jihadisme di Indonesia. Yogyakarta: Komunitas Bambu, 2011.

Stanton, Charles Michael. Pendidikan Tinggi dalam Islam, trans. H. Afandi Mochtar and Hasan Asari. Jakarta: Logos, 1994.

Suhandang, Kustadi. Retorika Strategi, Teknik, dan Taktik Pidato. Bandung: Nuansa, 2009.

Taba, Abdul Aziz. Islam dan Negera dalam Politik Orde Baru. Jakarta, Gema Insani Press, 1996.

Undang-undang Otonomi Daerah 1999

Wibisono. Koento. Arti Perkembangan Menurut Filsafat Positivisme Auguste Comte. Yogyakarta: Gadjah Mada University Press, 1983.

Wehr, Hans. A Dictionary of Modern Written Arabic. London: Macdonald \& Evans Ltd., 1974.

Zanki, Nurudin. "Perpindahan Ibukota Pemerintahan Kabupaten Semarang dari Kota Semarang ke Kota Ungaran Tahun 19711983." Journal of Indonesian History 3, 1 (2014).

\section{Internet Sources}

http://okberita.com/merajut-jembatan-persaudaraan-sejati/, Accessed on January 12, 2017.

https://rangkaijejak.wordpress.com/ 2014/09/26/ kota-dingin-bajawa/. accessed on January 26, 2017.

http://www.hipwee.com/feature/masih-ribut-ribut-soal-tolikara-masjid-dan-gereja-ini-bertahun-tahun-hidup-berdampingan-dengandamai/ accessed on January 26, 2017.

http:/ jogja.tribunnews.com/2015/07/21/wow-masjid-dan-gereja-disolo-ini-saling-berdampingan. Accessed on January 28, 2017. 
http://www.antarajatim.com/lihat/ berita/126757/dubes-as-apresiasimasjid-al-akbar-gereja-berdekatan. Accessed on January 26, 2017.

http://www.kompasiana.com/mahajinoesa/sejuknya-mesjid-dan-gereja-berhimpit-di-kota-kendari 55ace4ffb27a616c080d4b58, accessed on January 26, 2017.

http://www.matakalbar.com/ baca/653/ 2014-10-02/ masjid.dan.gereja. berdiri. berdampingan.sebagai. simbol.toleransi, Accessed on January 27,2017

http://www.hipwee.com/feature/masih-ribut-ribut-soal-tolikara-masjid-dan-gereja-ini-bertahun-tahun-hidup-berdampingan-dengandamai/. accessed on January 26, 2017.

http://wongcrewchild.blogspot.co.id/2014/12/simbol-toleransi-dialun-alun-kota.html. accessed on January 26, 2017.

http://pa.uinsgd.ac.id/sikap-umat-beragama-kristen-dan-islam-terhadap-keberadaan-masjid-dan-gereja-yang-berdekatan-lokasinyadi-sarijadi-bandung/ accessed on January 26, 2017.

https://id.wikipedia.org/wiki/Kabupaten_Semarang accessed on 20 April 2017.

https://www.tripadvisor.co.id/ShowUserReviews-g3207850-d8326958-r280793216-Avalokitesvara Sri Kukusrejo Temple-Ungaran_Central_Java_Java.html. accessed on April 18, 2017.

http://www.suaramerdeka.com/harian/0612/20/kot31.htm, Accessed on February 5, 2017.

http:/ $/$ batamtex.com $/$ nw $/$ index.php? option $=$ com content\&task $={ }_{\mathrm{V}}$ iew\&id=6\&Itemid=29, accessed on February 4, 2017.

http://swa.co.id/swa/trends/management/ungaran-sari-garment-kuasai-amerika, accessed on February 3, 2017

https://www.translate.com/english/pt-nissin-biscuit-indonesia-didirikan-pada-ungaran-jawa-tengah-indonesia-pada-8-hektar-inimulai/25516800, accessed on January 3, 2017.

http:// www. lokerindonesia.com/ teknik/lowongan-supervisor- produksi-pt-poliplas-makmur-santosa.html. Accessed on February 3, 2017. 
http:// e-journal.uajy.ac.id/3925/3/2KOM03842.pdf. accessed on 3 February 2017).

http://siapa.co.id/2015/05/01/siapa-pendiri-harian-suara-merdeka/. accessed on April 21, 2017.

\section{Interviews}

Interview with Ahmad Thoha. Youth activist of the Istiqomah mosque in the $90 \mathrm{~s}$. He is also a chairman of the Istiqomah Foundation.

Interview with Endro Utomo, Youth activist of the Istiqomah mosque in the ' $80 \mathrm{~s}$.

Interview with Latif, Itiqomah Mosque's operational officer since 1987 until now.

Interview with Mas'an Karno, Secretary I of the Istiqomah mosque's committee of the construction.

Interview with Mastur Irfan, Former secretary deputy of Golkar in the early of the ' 80 s.

Interview with Mohammad Ridwan, One of the founders of the Istiqomah foundation. He is now the Imam of Istiqomah Mosque.

Interview with Nurul Fadlilah, Reciter of the verse of the Holy Qur'an at the inauguration of Istiqomah mosque.

Interview with Soesmono Martosiswojo, Former Regent of Semarang, ex-officio chairman of Istigomah Foundation period 1979-1985

Interview with Sarjono, Former Junior High School teacher of the Regional Government (Pemda) in Ungaran in the "70s.

Interview with Soepeno Hadi, One of the Istiqomah mosque's committee of the construction.

Interview with Tatik Koesnadi, Former teacher and head of the State Junior High School in the "70s in Ungaran

Interview with Toni Irianto, Youth activist of Istiqomah mosque in the '80s.

Interview with Yasin Anwar, Public figure in Ungaran.

Interview with Zaenal Abidin, Recent chairman of Takmir of Istiqomah mosque. Former employee of Plantation of Central Java Province. 


\section{Archives and Inscriptions}

Notarial Deed of the establishment of Istiqomah Foundation, Notary H. Pandji Surya SH., Notary in Semarang Jalan Let. Jend. M.T. Haryono No. 515, Copy, dated September 28, 1978, Number 6.

Notarial Deed of the Istiqomah Foundation, Notary Achmad Dimyati, S.H. In Ambarawa Kab. Semarang dated February 1, 1989.

Notarial Deed No. 55 dated December 29, 2015, drawn up by notary Rika Budi Antawati, SH., M.Kn.

Decree of the Minister of Justice and Human Rights of the Republic of Indonesia Number AHU-0033995.AH.01.04. Year 2015.

Main Book of Raudhatul Athfal/Bustanul Athfal and Perwanida II / Istiqomah Kindergarten of Ungaran year 1988/1989.

Main Book of Raudhatul Athfal/Bustanul Athfal and Perwanida II / Istiqomah Kindergarten of Ungaran year 1999/ 2000.

Book of the Istiqomah Islamic School Monthly Report in 1999/2000. Main book of Istigomah Kindergarten and Elementary School in 1991/1992.

Main book of Islamic Istiqomah Elementary School in 1991/1992.

Inscription of the inauguration of Istiqomah Mosque. 
Muh. Saerozi

$458 \mid$\begin{tabular}{l|l} 
JOURNAL OF INDONESIAN ISLAM \\
VOLUME 1 1, NUMBER O2, DECEMBER 2017
\end{tabular} 